\title{
Pengukuran Kinerja Perusahaan Menggunakan Analytic Network Process (ANP) pada Balanced Scorecard (BSC) dengan Pendekatan Fuzzy
}

\author{
Khoirun Nisa ${ }^{\# 1}$

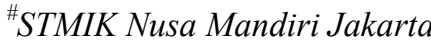 \\ Jl. Damai No.8 Warung Jati Barat (Margasatwa) Jakarta Selatan \\ ${ }^{1}$ khoirun. khnenusamandiri.ac.id
}

\begin{abstract}
Abstrak-Dunia bisnis semakin kompetitif sehingga tantangan yang dihadapi oleh organisasi baik yang berorientasi laba maupun tidak menjadi semakin kompleks. Tantangan yang dihadapi tidak hanya dari dalam perusahaan seperti tantangan terbatasnya modal, sumber daya manusia dan menurunnya produktivitas tetapi juga tantangan yang berasal dari luar perusahaan. Tantangan yang berasal dari luar perusahaan, yaitu semakin tingginya tuntutan dari pelanggan dan tekanan dari pemerintah serta perkembangan teknologi yang semakin canggih. Balanced Scorecard merupakan kerangka manajemen yang digunakan dalam pengukuran kinerja perusahaan. Pengukuran kinerja perusahaan menggunakan empat perspektif yaitu perspektif keuangan, perspektif pelanggan, perspektif proses bisnis internal serta perspektif pembelajaran dan perkembangan. Tim pakar perusahaan telah menentukan indikator kinerja berdasarkan perspektif BSC. Tujuan penelitian adalah untuk mengukur kinerja Perusahaan menggunakan Fuzzy Analytic Network Process (FANP) dengan konsep Balance Scorecard. BSC digunakan bukan hanya mengukur kinerja dari aspek keuangan saja tetapi juga mempertimbangkan kinerja dari aspek non keuangan. Hasil dari penelitian ini adalah Perusahaan tersebut telah menjalankan perusahaannya berdasarkan indikator kinerja dari perspektif BSC yang sesuai dengan visi dan strategi menggunakan $F u z z y$ Analytic Network Process (FANP) sebesar 88,31\%.
\end{abstract}

Kata kunci - Kinerja Perusahaan, Balanced Scorecard, Fuzzy, ANP, FANP

\section{PENDAhUluan}

Berkembangnya suatu Perusahaan juga seiring dengan dihadapinya masalah-masalah yang rumit. Dengan adanya revolusi informasi dan terbukanya perekonomian dunia, maka semakin tidak terlihatnya batas perdagangan antar negara maupun regional dan meningkatnya tuntutan konsumen terhadap pasar.

Tugas penting bagi para pemimpin organisasi perusahaan adalah menilai kinerja perusahaan. Penilaian kinerja secara periodik memungkinkan pemimpin organisasi perusahaan mengetahui posisi perusahaan saat ini dibandingkan dengan target atau sasaran yang telah ditetapkan misalnya, atau dibandingkan dengan pesaing dan rata-rata industri.

Kinerja merupakan gambaran mengenai tingkat pencapaian pelaksanaan suatu program kegiatan atau kebijakan dalam mewujudkan sasaran, tujuan, visi dan misi organisasi yang dituangkan melalui perencanaan strategis suatu organisasi. Pengukuran kinerja atau performance merupakan gambaran mengenai tingkat pencapaian pelaksanaan sesuatu program kegiatan atau kebijakan dalam mewujudkan sasaran, tujuan, visi dan misi organisasi yang dituangkan melalui perencanaan strategis suatu organisasi [1].

Pengukuran kinerja merupakan suatu hal yang penting dalam proses perencanaan, pengendalian, dan proses transaksional seperti merger, akuisisi, dan emisi saham. Melalui penilaian, perusahaan dapat memilih strategi dan struktur keuangan yang tepat, menentukan phase out terhadap unit-unit bisnis perusahaan yang tidak produktif, menetapkan balas jasa (reward) internal dan menentukan harga saham secara wajar.

Penilaian kinerja dilakukan bertujuan untuk menentukan kontribusi sebuah bagian atau tim dalam perusahaan terhadap suatu organisai perusahaan secara keseluruhan, memberikan penilaian mutu prestasi bagian dalam perusahaan dan memberikan motivasi bagi seluruh bagian dalam perusahaan.

Konsep balanced scorecard merupakan suatu sarana untuk mengkomunikasikan persepsi strategis dalam suatu perusahaan secara sederhana dan mudah dimengerti oleh berbagai pihak dalam perusahaan, terutama pihak-pihak dalam organisasi yang akan merumuskan strategi perusahaan [2].

Indikator atau ukuran keberhasilan kinerja perlu disusun untuk mengetahui keberhasilan kinerja. Ukuran keberhasilan kinerja merupakan standar penilaian kinerja perusahaan dengan menggunakan perspektif tertentu yang harus dievaluasi secara periodik dan berkesinambungan[3]. 
Balanced scorecard pertama kali diperkenalkan oleh Kaplan \& Norton di Harvard Business Review edisi Januari-Februari 1992. Balanced scorecard tersebut digunakan Kaplan \& Norton sebagai salah satu alat manajemen strategi yang terdiri dari satu rangkaian pengukuran dan dapat memberikan gambaran non keuangan. Balanced scorecard cocok satu sama lain dengan activity based responsibility accounting, karena memfokuskan pada proses dan memerlukan penggunaan informasi berbasis aktifitas untuk menerapkan banyak tujuan dan tolak ukurnya.

BSC merupakan sistem pengukuran kinerja yang komprehensif, dimana pengukuran yang dilakukan berdasarkan empat aspek yang saling melengkapi. Dengan dilakukanya pengukuran kinerja perusahaan menggunakan BSC, kinerja perusahaan akan terlihat secara keseluruhan dari aspek keuan- gan dan non keuangannya, dari internal maupun dari eksternal perusahaan [4].

\section{URAIAN PENELITIAN}

Penelitian dengan menggunakan konsep Balanced Scorecard sudah pernah dilakukan oleh peneliti lain. Seperti analisis kinerja manajemen rumah sakit dengan pendekatan balanced scorecard dan analisis deskriptif [4]. Selain itu ada pula penelitian menganalisis tingkat kinerja RSUD dengan metode BSC dan menggunakan analisis deskriptif kuantitatif dengan cara pengambilan sampel menggunakan rumus slovin [5].

Penelitian juga dilakukan pada sektor komersial UMKM yang bertujuan untuk mengetahui seberapa besar kontribusi penerapan Balanced Scorecard (BSC) dengan menggunakan empat perspektif: keuangan, pelanggan, proses bisnis internal dan pembelajaran dan pertumbuhan. Konsep Balanced Scorecard dianggap sesuai dengan pertimbangan bahwa konsep ini mampu menyeimbangkan rencana jangka pendek dengan rencana jangka panjang, serta menyeimbangkan kinerja keuangan dengan kinerja non- keuangan [6] .

Peningkatan tata kelola IT juga dilakukan dengan integrasi antara Balanced Scorecard dengan COBIT 5 [7].

Analisis pencapaian strategi menggunakan Balanced Scorecard juga dilakukan oleh Dinas Pendidikan Kota Surabaya dalam mening- katkan mutu pendidikan di Kota Surabaya tahun 2015 telah tercapai dengan baik hal ini ditunjukan dengan capaian NKU sebesar 102,31\% yang berarti telah memenuhi target yang telah ditetapkan $100 \%$ [8].

Dan pada penelitian ini, peneliti menggunakan pendekatan Fuzzy Analytic Network Process (FANP) dengan konsep Balancerd Scorecard.

\section{A. Fuzzy Analytical Network Process (FANP)}

Konsep tentang logika fuzzy diperkenalkan oleh prof.Lotfi Astor Zadeh pada tahun 1965, logika fuzzy adalah metodelogi sistem control pemecah masalah, yang cocok untuk diimplementasikan pada sistem, mulai dari sistem yang sederhana, sistem kecil, embedded sistem, jaringan PC, multi channel atau workstation berbasis akuisi data dan sistem control [9].

Metode Analytic Network Process (ANP) merupakan pengembangan dari metode Analytical Hierarchy Process (AHP). Analytical Hierarchy Process (AHP) adalah salah satu metode yang digunakan untuk menyelesaikan pengambilan keputusan dengan multikriteria atau Multi Criteria Decision Making (MCDM). AHP diperkenalkan oleh Prof. Thomas Lorie Saaty pada periode 1971-1975 ketika di Wharton Business SchooL. AHP mempunyai kelemahan yaitu, tidak memperhatikan keterkaitan antar kriteria atau alternatif [10].

ANP merupakan sebuah metode jaringan yang membandingkan semua hal termasuk kriteria dan alternatif yang ada sehingga mendapatkan suatu super matriks yang sangat kompleks [11].

Fuzzy ANP merupakan suatu metode yang menggabungkan metode fuzzy dengan ANP. ANP sangat sesuai untuk kondisi dimana sangat banyak ketergantungan terjadi dalam pengambilan keputusan. Proses ANP membutuhkandata perbandingan berpasangan. Dalam memperoleh data matriks berpasangan tersebut akan dibutuhkan subjektivitas dari masing-masing responden dalam melakukan perbandingan. [12].

\section{B. Balanced Scorecard (BSC)}

Penggunaan balanced scorecard (BSC) telah menyebar luas sebagai pengukuran kinerja dan sistem manajemen. Pendekatan BSC telah diperkenalkan oleh Kaplan dan Norton pada tingkat perusahaan. Premis dasar mereka adalah bahwa evaluasi dari suatu perusahaan seharusnya tidak terbatas pada evaluasi keuangan tradisional tetapi harus dilengkapi dengan langkah-langkah mengenai kepuasan pelanggan, proses internal dan pembelajaran dan pertumbuhan[13].

Balanced scorecard pertama kali diperkenalkan oleh Kaplan dan Norton pada tahun 1992 sebagai seperangkat pengukuran kinerja yang memberi manajemen puncak pandangan yang cepat dan komprehensif tentang perusahaan. BSC memasukkan ukuran- ukuran finansial yang memberi hasil yang telah dilakukan dan melengkapinya dengan ukuranukuran operasional diantaranya ke- puasan pelanggan, proses internal dan inovasi dan perkembangan[14].

Balanced Scorecard merupakan alat pengukur kinerja yang tidak hanya mengukur kinerja dari segi keuangan saja tetapi juga dari segi non keuangan yang terdiri dari empat perspektif yang saling melengkapi dan mempunyai hubungan sebab akibat. Dengan menggunakan Balanced Scorecard, manajer tidak hanya mengukur hasil akhir, tetapi juga mengukur aktivitas-aktivitas penentu akhir. Hal ini karena Balanced Scorecard bukan hanya sekedar alat pengukur kinerja suatu perusahaan tetapi juga merupakan suatu bentuk usaha manajemen yang strategis pada seluruh tingkatan organisasi, dengan kata lain metode ini merupakan usaha organisasi [5].

Balanced Scorecard mencari suatu keseimbangan dari tolok ukur kinerja keuangan maupun non-keuangan untuk mengarahkan kinerja organisasional terhadap keberhasilan 
perusahaan. Balanced scorecard merupakan suatu sistem yang menjabarkan misi dan strategi suatu organisasi kedalam tujuan operasional dan tolok ukur kinerja perusahaan tersebut. Pengukuran yang selama ini sering digunakan oleh perusahaan yaitu dengan pengukuran yang hanya mengukur kinerja keuangan atau jangka pendek saja dan tidak dapat menggambarkan kinerja perusahaan secara keseluruhan.

Untuk mengatasi kekurangan tersebut maka diciptakan pengukuran kinerja yang mempertimbangkan aspek dari keuangan dan non keuangan yang disebut dengan metode Balanced Scorecard [15].

\section{METODOOGI}

Metode yang digunakan pada penelitian ini adalah Fuzzy Analytical Network Process (FANP) dengan Konsep Balanced Scorecard. Adapun tahapan FANP-BSC sebagai berikut :

1) Penyusunan tahapan dalam Balanced Scorecard (BSC) yaitu :

a) Membentuk tim evaluasi kinerja dari pakar perusahaan dan menentukan visi bisnis

b) Menentukan strategi yang akan dijalani agar mencapai visi bisnis

c) Menentukan indikator kinerja berdasarkan perspektif

2) Penyusunan tahapan BSC menggunakan metode FANP, yaitu :

a) Membentuk struktur hierarki model ANP (visi, strategi, perspektif BSC, indikator kinerja).

b) Menentukan bobot loKal dari strategi, perspektif BSC dan indikator kinerja menggunakan matriks perbandingan berpasangan (pairwise comparison matrices)(dengan asumsi bahwa tidak ada keterkaitan antar perspektif BSC). Skala fuzzy yang berhubungan. dengan skala kepentingan untuk mengukur bobot relatif digunakan metode Extent Analysis.

c) Menentukan matriks inner dependence dari BSC perspektif yang berhubungan (berdasarkan

d) Menghitung bobot keterkaitan (independent weights) dengan cara mengalikan matriks inner dependence dengan bobot local perspektif BSC yang telah ditentukan

e) Menghitung bobot global untuk indikator kinerja dengan mengalikan bobot local indikator kinerja dengan bobot keterkaitan (interdependent weights).

f) Mengukur indikator kinerja

g) Menghitung kinerja bisnis menggunakan bobot global

\section{HASIL DAN PEMBAHASAN}

\section{A. PENERAPAN FANP-BSC}

Salah satu Perusahaan di Indonesia yang bergerak di bidang Penjualan dan Distribusi ingin mengukur kinerja perusahaannya dengan visi "Sukses dan Unggul sebagai perusahaan sales dan distributor", dan memiliki tiga strategi, yaitu :

\section{1) Strategi 1 :}

Merancang produk berdasarkan kemauan konsumen.

2) Strategi 2 :

Mengembangkan teknologi yang digunakan dalam phase penjualan dan distribusi.

3) Strategi 3 :

Mengembangkan bisnis principal yang sudah ada Tim pakar perusahaan telah menentuakn indikator kinerja berdasarkan perspektif BSC.

TABEL I

PERSPEKTIF BSC DAN INDIKATORNYA

\begin{tabular}{|c|l|}
\hline \multirow{2}{*}{ Perspektif BSC } & \multicolumn{1}{c|}{ Indikator } \\
\hline \multirow{4}{*}{ Perspektif Keuangan } & Pertumbuhan Pendapatan \\
\cline { 2 - 3 } & Peningkatan Produktifitas \\
\cline { 2 - 2 } & Optimalisasi Aset \\
\hline \multirow{4}{*}{ Persepktif Pelanggan } & Perolehan Pelanggan Baru \\
\cline { 2 - 2 } & Customer Profitability \\
\hline \multirow{4}{*}{\begin{tabular}{c} 
Proses Internal Bisnis \\
\cline { 2 - 2 }
\end{tabular}} & Perkembangan Bisnis Principal \\
\cline { 2 - 2 } & Jasa Pengiriman Produk \\
\cline { 2 - 2 } & Promosi Produk \\
\hline \multirow{2}{*}{$\begin{array}{c}\text { Proses Pembelajaran } \\
\text { dan Perkembangan }\end{array}$} & $\begin{array}{l}\text { Berbagi pengetahuan dan } \\
\text { keterampilan }\end{array}$ \\
\cline { 2 - 2 } & Pelatihan Karyawan \\
\cline { 2 - 2 } & Keterbukaan berkomunikasi \\
\hline
\end{tabular}

Berdasarkan penyusunan tahapan Balanced Scorecard (BSC) dengan Metode FANP, maka langkah-langkahnya sebagi berikut :

1) Tahap 1 :

Membentuk struktur hierarki model ANP (visi, strategi, perspektif BSC, indikator kinerja).

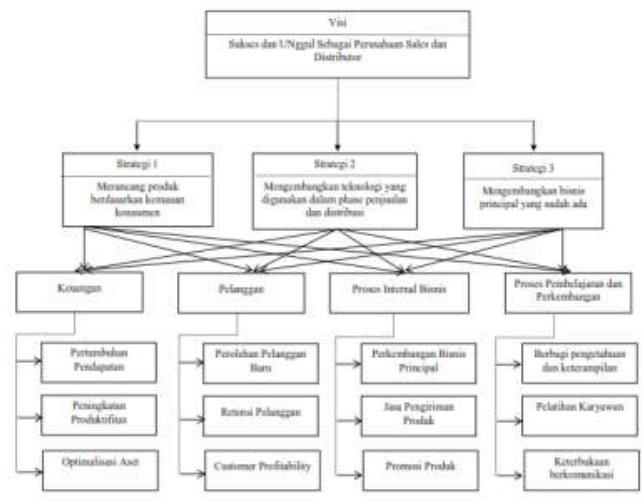

Gambar. 1 Struktur hirarki FANP-BSC 
2) Tahap 2 :

Menentukan bobot lokal dari strategi, perspektif BSC dan indikator kinerja menggunakan matriks perbandingan berpasangan (pairwise comparison matrices) (dengan asumsi bahwa tidak ada keterkaitan antar perspektif BSC).
Untuk memperoleh hasil penjumlahan baris pada tabel diatas, diperoleh dengan cara : $(1 ; 1 ; 1)+(0,67 ; 1 ; 2)+(0,33 ; 0,4$; $0,5)=(1+0,67+0,33 ; 1+1+0,4 ; 1+2+0,5)$

TABEL II

PERSPEKTIF BSC DAN INDIKATORNYA

\begin{tabular}{|c|c|c|c|c|c|c|c|c|c|c|c|c|}
\hline \multirow{2}{*}{ STRATEGI } & \multicolumn{3}{|c|}{ STRATEGI 1} & \multicolumn{3}{|c|}{ STRATEGI 2} & \multicolumn{3}{|c|}{ STRATEGI 3} & \multicolumn{3}{|c|}{ Jumlah Baris } \\
\hline & 1 & $\mathbf{m}$ & $\mathbf{u}$ & 1 & $\mathbf{m}$ & $\mathbf{U}$ & 1 & $\mathbf{m}$ & $\mathbf{u}$ & 1 & $\mathbf{m}$ & $\mathbf{u}$ \\
\hline STRATEGI 1 & 1,00 & 1,00 & 1,00 & 0,67 & 1,00 & 2,00 & 0,33 & 0,40 & 0,50 & 2,00 & 2,40 & 3,50 \\
\hline STRATEGI 2 & 0,50 & 1,00 & 1,50 & 1,00 & 1,00 & 1,00 & 0,40 & 0,50 & 0,67 & 1,90 & 2,50 & 3,17 \\
\hline STRATEGI 3 & 2,00 & 2,50 & 3,00 & 1,50 & 2,00 & 2,50 & 1,00 & 1,00 & 1,00 & 4,50 & 5,50 & 6,50 \\
\hline \multicolumn{10}{|c|}{ Jumlah Kolom } & 8,40 & 10,40 & 13,17 \\
\hline
\end{tabular}

Setelah diperoleh jumlah baris dan jumlah kolom, maka selanjutnya diperoleh Nilai sintetis fuzzy dengan cara :

$$
s_{i}=\sum_{j=1}^{m} M_{g_{1}}^{j} \cdot\left[\sum_{i=1}^{n} \sum_{j=1}^{m} M_{g_{i}}^{j}\right]^{-1}
$$

Berikut adalah cara memperoleh nilai sintetis fuzzy dari masing-masing strategi:

Strategi 1.

$(2,00 ; 2,40 ; 3,50) \times\left(\frac{1}{13,17} ; \frac{1}{10,40} ; \frac{1}{8,40}\right)=(0,15 ; 0,23 ; 0,42)$

Strategi 2

$(1,90 ; 2,50 ; 3,17) \times\left(\frac{1}{13,17} ; \frac{1}{10,40} ; \frac{1}{8,40}\right)=(0,14 ; 0,24 ; 0,38)$ Strategi 3.

$(4,50 ; 5,50 ; 6,50) \times\left(\frac{1}{13,17} ; \frac{1}{10,40} ; \frac{1}{8,40}\right)=(0,34 ; 0,53 ; 0,77)$

Hasil sintetis fuzzy dari ketiga strategi dapat ditunjukkan oleh Tabel 3 .

TABEL III

NiLAi SinTETIS FuZZY UNTUK STRATEGi

\begin{tabular}{|l|c|c|c|}
\hline \multirow{2}{*}{ Strategi } & \multicolumn{3}{|c|}{ Nilai Sintetis Fuzzy } \\
\cline { 2 - 4 } & \multicolumn{1}{|c|}{$\mathbf{l}$} & \multicolumn{1}{c|}{ m } & \multicolumn{1}{c|}{ u } \\
\hline Strategi 1 & 0,15 & 0,23 & 0,42 \\
\hline Strategi 2 & 0,14 & 0,24 & 0,38 \\
\hline Strategi 3 & 0,34 & 0,53 & 0,77 \\
\hline
\end{tabular}

Selanjutnya yaitu memperoleh degree of possibility dari nilai sintetis fuzzy pada masing-masing strategi.

Untuk memperoleh degree of possibility digunakan persamaan berikut :

$$
V\left(s_{i} \equiv s_{j}\right)-\left\{\begin{array}{cc}
1 & \text {,jika } m_{j} \geq m_{i} \\
0 & \text { jika } u_{i} \leq L_{j} \\
l_{j}-u_{i} & \text {,jika yang latrnya }
\end{array}\right.
$$

Berikut adalah langkah untuk mendapatkan degree of possibility:

1) Perbandingan Strategi 1 dengan Strategi 2 dan Strategi 3

$V\left(S_{1} \geq S_{2}\right)=\frac{l_{L}-u_{1}}{\left(m_{1}-u_{2}\right)-\left(m_{2}-l_{2}\right)}=\frac{0,14-0,42}{(0,23-0,42)-(0,24-0,14)}=0,97$

$V\left(S_{1} \geq S_{3}\right)=\frac{l_{3}-u_{1}}{\left(m_{1}-u_{1}\right)-\left(m_{1}-l_{3}\right)}=\frac{0,34-0,42}{(0,23-0,42)-(0,53-0,34)}=0,20$

Dari derajat keanggotaan atau degree of possibility

yang diperoleh diatas kemudian diambil nilai

minimumnya.

Didapat

$$
d^{\prime}\left(A_{i}\right)=\min S_{i} \geq S_{j}
$$

$$
d^{\prime}(\text { Strategi } 1)=\min (0,97 ; 0,20)=0,20
$$

2) Perbandingan Strategi 2 dengan Strategi 1 dan Strategi 3

$$
\begin{aligned}
& V\left(S_{2} \geq S_{1}\right)=1 \\
& V\left(S_{2} \geq S_{3}\right)=\frac{l_{3}-u_{2}}{\left(m_{2}-u_{2}\right)-\left(m_{3}-l_{3}\right)}=\frac{0,34-0,38}{(0,24-0,38)-(0,53-0,34)}=0,11 \\
& \text { Didapat } \\
& d^{\prime}(\text { Strategi 2) }=\min (1 ; 0,11)=0,20
\end{aligned}
$$

3) Perbandingan Strategi 3 dengan Strategi 1 dan Strategi 2

Didapat

$$
\begin{aligned}
& V\left(S_{3} \geq S_{1}\right)=1 \\
& V\left(S_{3} \geq S_{2}\right)=1
\end{aligned}
$$

$d^{\prime}($ Strategi 3$)=\min (1 ; 1)=1$ 
Dari perhitungan diatas diperoleh bobot vektor yaitu $(0,20 ; 0,11 ; 1,00)^{t}$

Setelah diperoleh bobot vektor untuk masing-masing strategi, maka dilakukan normalisasi bobot dengan membagi masing-masing bobot dengan jumlah bobot keseluruhan. Hasil dari Degree of Possibility serta bobot ternormalisasi dapat dilihat dari Tabel 4 berikut.
Setelah bobot ternormalisasi, maka didapatkan nilai vektor bobot normal yang menyatakan nilai kontribusi pada masing-masing strategi pada perusahaan, yaitu strategi 1 sebesar $15,33 \%$, strategi 2 sebesar $8,31 \%$ dan strategi 3 sebesar $76,36 \%$. Proses selanjutnya dilakukan untuk setiap perspektif dalam BSC, dan didapatkan tabel bobot berikut:

TABEL IV

DEGREE OF POSSIBILITY

\begin{tabular}{|l|r|r|r|c|c|}
\hline \multirow{2}{*}{ Strategi } & \multicolumn{3}{|c|}{ Degree of Possibility } & \multirow{2}{*}{$\boldsymbol{d}^{\prime}$ (Strategi) } & \multirow{2}{*}{ Bobot } \\
\cline { 2 - 4 } & Strategi 1 & Strategi 2 & Strategi 3 & & \\
\hline Strategi 1 & & 0,97 & 0,20 & 0,20 & $\mathbf{0 , 1 5 3 3 3 3 8 1}$ \\
\hline Strategi 2 & 1,00 & & 0,11 & 0,11 & $\mathbf{0 , 0 8 3 0 7 0 4 8}$ \\
\hline Strategi 3 & 1,00 & 1,00 & & 1,00 & $\mathbf{0 , 7 6 3 5 9 5 7 2}$ \\
\hline
\end{tabular}

TABEL V

Bobot LOKAL DAN MATRIKS PERBANDINGAN KEPENTINGAN BERPASANGAN ANTAR PERSPEKTIF BSC PADA MASING-MASING STRATEGI

\begin{tabular}{|c|c|c|c|c|c|c|c|c|c|c|c|c|c|}
\hline \multirow{2}{*}{ Perspektif BSC } & \multicolumn{3}{|c|}{$\mathrm{K}$} & \multicolumn{3}{|c|}{$\mathrm{P}$} & \multicolumn{3}{|c|}{ PIB } & \multicolumn{3}{|c|}{$\mathrm{PP}$} & \multirow{2}{*}{ Bobot } \\
\hline & 1 & $\mathrm{~m}$ & $\mathrm{u}$ & 1 & $\mathrm{~m}$ & $\mathrm{u}$ & 1 & $\mathrm{~m}$ & $\mathrm{u}$ & 1 & $\mathrm{~m}$ & $\mathrm{u}$ & \\
\hline \multicolumn{14}{|c|}{ STRATEGI 1} \\
\hline KEUANGAN (K) & 1,00 & 1,00 & 1,00 & 1,00 & 1,50 & 2,00 & 0,50 & 1,00 & 1,50 & 1,00 & 1,50 & 2,00 & 0,299604987 \\
\hline PELANGGAN (P) & 0,50 & 0,67 & 1,00 & 1,00 & 1,00 & 1,00 & 0,50 & 1,00 & 1,50 & 1,50 & 2,00 & 2,50 & 0,281126238 \\
\hline $\begin{array}{l}\text { PROSES INTERNAL } \\
\text { BISNIS (PIB) }\end{array}$ & 0,67 & 1,00 & 2,00 & 0,67 & 1,00 & 2,00 & 1,00 & 1,00 & 1,00 & 1,50 & 2,00 & 2,50 & 0,299604987 \\
\hline $\begin{array}{l}\text { PROSES } \\
\text { PEMBELAJARAN DAN } \\
\text { PERKEMBANGAN (PP) }\end{array}$ & 0,50 & 0,67 & 1,00 & 0,40 & 0,50 & 0,67 & 0,40 & 0,50 & 0,67 & 1,00 & 1,00 & 1,00 & 0,119663787 \\
\hline \multicolumn{14}{|c|}{ STRATEGI 2} \\
\hline KEUANGAN (K) & 1,00 & 1,00 & 1,00 & 1,00 & 1,50 & 2,00 & 0,50 & 1,00 & 1,50 & 0,50 & 1,00 & 1,50 & 0,276162182 \\
\hline PELANGGAN (P) & 0,50 & 0,67 & 1,00 & 1,00 & 1,00 & 1,00 & 0,50 & 0,67 & 1,00 & 0,33 & 0,40 & 0,50 & 0,065354811 \\
\hline $\begin{array}{l}\text { PROSES INTERNAL } \\
\text { BISNIS (PIB) }\end{array}$ & 0,67 & 1,00 & 2,00 & 1,00 & 1,50 & 2,00 & 1,00 & 1,00 & 1,00 & 0,40 & 0,50 & 0,67 & 0,243245007 \\
\hline $\begin{array}{l}\text { PROSES } \\
\text { PEMBELAJARAN DAN } \\
\text { PERKEMBANGAN (PP) }\end{array}$ & 0,67 & 1,00 & 2,00 & 2,00 & 2,50 & 3,00 & 1,50 & 2,00 & 2,50 & 1,00 & 1,00 & 1,00 & 0,415238 \\
\hline \multicolumn{14}{|c|}{ STRATEGI 3} \\
\hline KEUANGAN (K) & 1,00 & 1,00 & 1,00 & 0,50 & 1,00 & 1,50 & 0,50 & 1,00 & 2,50 & 1,50 & 2,00 & 2,50 & 0,328252299 \\
\hline PELANGGAN $(\mathrm{P})$ & 0,67 & 0,67 & 2,00 & 1,00 & 1,00 & 1,00 & 0,33 & 0,40 & 0,50 & 1,00 & 1,50 & 2,00 & 0,21241747 \\
\hline $\begin{array}{l}\text { PROSES INTERNAL } \\
\text { BISNIS (PIB) }\end{array}$ & 0,40 & 1,00 & 2,00 & 2,00 & 2,50 & 3,00 & 1,00 & 1,00 & 1,00 & 2,00 & 2,50 & 3,00 & 0,442789935 \\
\hline $\begin{array}{l}\text { PROSES } \\
\text { PEMBELAJARAN DAN } \\
\text { PERKEMBANGAN (PP) }\end{array}$ & 0,40 & 0,50 & 0,67 & 0,50 & 0,67 & 1,00 & 0,33 & 0,40 & 0,50 & 1,00 & 1,00 & 1,00 & 0,016540296 \\
\hline
\end{tabular}


Bobot global dari perspektif BSC ditentukan dengan mengalikan bobot pada Tabel 5 dengan bobot strategi:

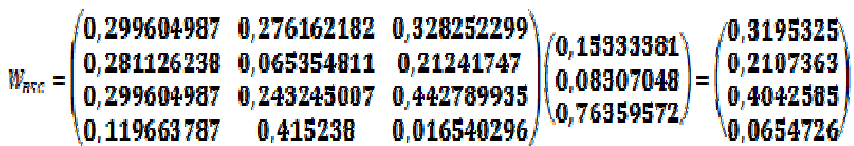

Dengan diasumsikan tidak ada hubungan antara perspektif BSC, terlihat bahwa perpektif Proses Internal Bisnis sangat menentukan dengan bobot sebesar 0.4042585 atau sebesar
40,42\% diikuti dengan perspektif Pelanggan sebesar 31,95\%, perspektif Keuangan sebesar 21,07\% dan perspesktif Proses Pembelajaran dan Perkembangan sebesar 6,55\%.

Pada akhir tahap 2 ini, akan ditentukan bobot dari indikator pada masing-masing perspektif, yaitu sebagai berikut: Pada akhir tahap 2 ini, akan ditentukan bobot dari indikator pada masing-masing perspektif, yaitu sebagai berikut:

TABEL VI

BOBOT LOKAL DARI INDIKATOR KINERJA

\begin{tabular}{|c|c|c|c|c|c|c|c|c|c|c|}
\hline \multirow[t]{2}{*}{ KEUANGAN } & \multicolumn{3}{|c|}{$\begin{array}{l}\text { Pertumbuhan } \\
\text { Pendapatan }\end{array}$} & \multicolumn{3}{|c|}{$\begin{array}{l}\text { Peningkatan } \\
\text { Produktifitas }\end{array}$} & \multicolumn{3}{|c|}{ Optimalisasi Aset } & \multirow[t]{2}{*}{ Bobot } \\
\hline & 1 & $\mathrm{~m}$ & $\mathrm{u}$ & 1 & $\mathrm{~m}$ & $\mathrm{u}$ & 1 & $\mathrm{~m}$ & $\mathrm{u}$ & \\
\hline Pertumbuhan Pendapatan & 1,00 & 1,00 & 1,00 & 0,40 & 0,50 & 0,67 & 1,50 & 2,00 & 2,50 & 0,376720682 \\
\hline Peningkatan Produktifitas & 1,50 & 2,00 & 2,50 & 1,00 & 1,00 & 1,00 & 1,00 & 1,50 & 2,00 & 0,546520755 \\
\hline Optimalisasi Aset & 0,40 & 0,50 & 0,67 & 0,50 & 0,67 & 1,00 & 1,00 & 1,00 & 1,00 & 0,076758564 \\
\hline \multirow[t]{2}{*}{ Pelanggan } & \multicolumn{3}{|c|}{$\begin{array}{c}\text { Perolehan Pelanggan } \\
\text { Baru } \\
\end{array}$} & \multicolumn{3}{|c|}{ Retensi Pelanggan } & \multicolumn{3}{|c|}{$\begin{array}{c}\text { Customer } \\
\text { Profitability }\end{array}$} & \multirow[t]{2}{*}{ Bobot } \\
\hline & 1 & $\mathrm{~m}$ & $\mathrm{u}$ & 1 & $\mathrm{~m}$ & $\mathrm{u}$ & 1 & $\mathrm{~m}$ & $\mathrm{u}$ & \\
\hline Perolehan Pelanggan Baru & 1,00 & 1,00 & 1,00 & 0,40 & 0,50 & 0,67 & 0,50 & 1,00 & 1,50 & 0,234538108 \\
\hline Retensi Pelanggan & 1,50 & 2,00 & 2,50 & 1,00 & 1,00 & 1,00 & 0,50 & 0,67 & 1,00 & 0,390358366 \\
\hline Customer Profitability & 0,67 & 1,00 & 2,00 & 1,00 & 1,50 & 2,00 & 1,00 & 1,00 & 1,00 & 0,375103526 \\
\hline \multirow[t]{2}{*}{ Proses Internal Bisnis } & \multicolumn{3}{|c|}{$\begin{array}{c}\text { Perkembangan Bisnis } \\
\text { Principal }\end{array}$} & \multicolumn{3}{|c|}{$\begin{array}{c}\text { Jasa Pengiriman } \\
\text { Produk }\end{array}$} & \multicolumn{3}{|c|}{ Promosi Produk } & \multirow[t]{2}{*}{ Bobot } \\
\hline & 1 & $\mathrm{~m}$ & $\mathrm{u}$ & 1 & $\mathrm{~m}$ & $\mathrm{u}$ & 1 & $\mathrm{~m}$ & $\mathrm{u}$ & \\
\hline $\begin{array}{c}\text { Perkembangan Bisnis } \\
\text { Principal }\end{array}$ & 1,00 & 1,00 & 1,00 & 0,50 & 1,00 & 1,50 & 1,00 & 1,50 & 2,00 & 0,369355401 \\
\hline Jasa Pengiriman Produk & 0,67 & 1,00 & 2,00 & 1,00 & 1,00 & 1,00 & 0,50 & 1,00 & 1,50 & 0,330669436 \\
\hline Promosi Produk & 0,50 & 0,67 & 1,00 & 0,67 & 1,00 & 2,00 & 1,00 & 1,00 & 1,00 & 0,299975162 \\
\hline \multirow{2}{*}{$\begin{array}{c}\text { Proses Pembelajaran dan } \\
\text { Perkembangan }\end{array}$} & \multicolumn{3}{|c|}{$\begin{array}{c}\text { Berbagi pengetahuan } \\
\text { dan keterampilan }\end{array}$} & \multicolumn{3}{|c|}{$\begin{array}{l}\text { Pelatihan } \\
\text { Karyawan }\end{array}$} & \multicolumn{3}{|c|}{$\begin{array}{c}\text { Keterbukaan } \\
\text { berkomunikasi }\end{array}$} & \multirow[t]{2}{*}{ Bobot } \\
\hline & 1 & $\mathrm{~m}$ & $\mathrm{u}$ & 1 & $\mathrm{~m}$ & $\mathrm{u}$ & 1 & $\mathrm{~m}$ & $\mathrm{u}$ & \\
\hline $\begin{array}{l}\text { Berbagi pengetahuan dan } \\
\text { keterampilan }\end{array}$ & 1,00 & 1,00 & 1,00 & 0,50 & 1,00 & 1,50 & 1,00 & 1,50 & 2,00 & 0,369355401 \\
\hline Pelatihan Karyawan & 0,67 & 1,00 & 2,00 & 1,00 & 1,00 & 1,00 & 0,50 & 1,00 & 1,50 & 0,330669436 \\
\hline Keterbukaan berkomunikasi & 0,50 & 0,67 & 1,00 & 0,67 & 1,00 & 2,00 & 1,00 & 1,00 & 1,00 & 0,299975162 \\
\hline
\end{tabular}

3) Tahap 3:

Menentukan matriks inner dependence dari BSC perspektif yang berhubungan (berdasarkan gambar 2), menggunakan skala fuzzy (Tabel 1). 
TABEL VII

MATRIKS INNER DEPENDENCE YANG BERHUBUNGAN DENGAN KeUANGAN

\begin{tabular}{|c|c|c|c|c|c|c|c|c|c|c|}
\hline \multirow{2}{*}{ KEUANGAN } & \multicolumn{3}{|c|}{$\mathrm{P}$} & \multicolumn{3}{|c|}{ PIB } & \multicolumn{3}{|c|}{ PP } & \multirow{2}{*}{ Bobot } \\
\hline & 1 & $\mathrm{~m}$ & $\mathrm{u}$ & 1 & $\mathrm{~m}$ & $\mathrm{u}$ & 1 & $\mathrm{~m}$ & $\mathrm{u}$ & \\
\hline PELANGGAN (P) & 1,00 & 1,00 & 1,00 & 0,50 & 1,00 & 1,50 & 1,50 & 2,00 & 2,50 & 0,457156698 \\
\hline $\begin{array}{l}\text { PROSES INTERNAL BISNIS } \\
\text { (PIB) }\end{array}$ & 0,67 & 1,00 & 2,00 & 1,00 & 1,00 & 1,00 & 1,50 & 2,00 & 2,50 & 0,457156698 \\
\hline $\begin{array}{l}\text { PROSES PEMBELAJARAN DAN } \\
\text { PERKEMBANGAN (PP) }\end{array}$ & 0,40 & 0,50 & 0,67 & 0,40 & 0,50 & 0,67 & 1,00 & 1,00 & 1,00 & 0,085686603 \\
\hline
\end{tabular}

TABEL VIII

Matriks INNER DePENDENCE YANG BERHUBUngan DENGAN PELANGGAN

\begin{tabular}{|c|c|c|c|c|c|c|c|c|c|c|}
\hline \multirow{2}{*}{ PELANGGAN } & \multicolumn{3}{|c|}{$\mathrm{K}$} & \multicolumn{3}{|c|}{ PIB } & \multicolumn{3}{|c|}{$\mathrm{PP}$} & \multirow{2}{*}{ Bobot } \\
\hline & 1 & $\mathrm{~m}$ & $\mathrm{u}$ & 1 & $\mathrm{~m}$ & $\mathrm{u}$ & 1 & $\mathrm{~m}$ & $\mathrm{u}$ & \\
\hline KEUANGAN (K) & 1,00 & 1,00 & 1,00 & 0,50 & 1,00 & 1,50 & 2,50 & 3,00 & 3,50 & 0,52923397 \\
\hline $\begin{array}{l}\text { PROSES INTERNAL BISNIS } \\
\text { (PIB) }\end{array}$ & 0,67 & 1,00 & 2,00 & 1,00 & 1,00 & 1,00 & 2,00 & 2,50 & 3,00 & 0,47076603 \\
\hline $\begin{array}{l}\text { PROSES PEMBELAJARAN } \\
\text { DAN PERKEMBANGAN (PP) }\end{array}$ & 0,29 & 0,33 & 0,40 & 0,33 & 0,40 & 0,50 & 1,00 & 1,00 & 1,00 & $\mathbf{0}$ \\
\hline
\end{tabular}

TABEL IX

MATRIKS INNER DEPENDENCE YANG BERHUBUNGAN DENGAN PROSES INTERNAL BISNIS

\begin{tabular}{|c|c|c|c|c|c|c|c|}
\hline \multirow{2}{*}{$\begin{array}{l}\text { Proses Internal } \\
\text { Bisnis (PIB) }\end{array}$} & \multicolumn{3}{|c|}{$\mathrm{K}$} & \multicolumn{3}{|c|}{$\mathrm{PP}$} & \multirow{2}{*}{ Bobot } \\
\hline & 1 & $\mathrm{~m}$ & $\mathrm{u}$ & 1 & $\mathrm{~m}$ & $\mathrm{u}$ & \\
\hline Keuangan (K) & 1,00 & 1,00 & 1,00 & 1,00 & 1,50 & 2,00 & 0,6842105 \\
\hline $\begin{array}{l}\text { Proses } \\
\text { Pembelajaran } \\
\text { dan } \\
\text { Perkembangan } \\
\text { (PP) }\end{array}$ & 0,50 & 0,67 & 1,00 & 1,00 & 1,00 & 1,00 & 0,3157894 \\
\hline
\end{tabular}

TABEL X

MATRIKS INNER DEPENDENCE YANG BERHUBUNGAN DENGAN PROSES PEMBELAJARAN DAN PERKEMBANGAN

\begin{tabular}{|c|c|c|c|c|c|c|c|}
\hline \multirow{2}{*}{$\begin{array}{c}\text { PROSES } \\
\text { PEMBELAJARAN } \\
\text { DAN } \\
\text { PERKEMBANGAN } \\
\text { (PP) }\end{array}$} & \multicolumn{3}{|c|}{ K } & \multicolumn{3}{|c|}{ PIB } & \multirow[b]{2}{*}{ Bobot } \\
\hline & 1 & $\mathrm{~m}$ & $\mathrm{u}$ & 1 & $\mathrm{~m}$ & $\mathrm{u}$ & \\
\hline Keuangan (K) & 1,00 & 1,00 & 1,00 & 2,50 & 3,00 & 3,50 & 1 \\
\hline $\begin{array}{l}\text { Proses Internal Bisnis } \\
\text { (PIB) }\end{array}$ & 0,29 & 0,33 & 0,40 & 1,00 & 1,00 & 1,00 & 0 \\
\hline
\end{tabular}

\section{4) Tahap 4:}

Menghitung bobot keterkaitan (independent weights) dengan cara mengalikan matriks inner dependence dengan bobot global perspektif BSC yang telah ditentukan BSC yang telah ditentukan pada tahap 2 .

$$
W_{B S C}=\left(\begin{array}{cccc}
1 & 0,53 & 0,68 & 1 \\
\mathbf{0}, 46 & 1 & 0 & 0 \\
0,46 & 0,47 & 1 & 0 \\
0,08 & 0 & 0,32 & 1
\end{array}\right)\left(\begin{array}{l}
\mathbf{0}, 3195325 \\
\mathbf{0}, 2107363 \\
\mathbf{0}, \mathbf{4 0 4 2 5 8 5} \\
\mathbf{0}, \mathbf{0 6 5 4 7 2 6}
\end{array}\right)=\left(\begin{array}{l}
0,77 \\
0,36 \\
0,65 \\
0,22
\end{array}\right)
$$

Bobot yang didapat dari hasil perkalian diatas kemudian dinormalisasikan sehingga menjadi

$$
W_{B S C}=\left(\begin{array}{l}
0,39 \\
0,18 \\
0,32 \\
0,11
\end{array}\right)
$$

Terlihat perbedaan pada bobot perspektif BSC ketika keterkaitan antar perspektif diperhatikan. Hasilnya berubah dari $31,95 \%$ menjadi $39 \% ; 21,07 \%$ menjadi $18 \% ; 40,42 \%$ menjadi $32 \%$ dan $6,54 \%$ menjadi $11 \%$ untuk masing-masing bobot perspektif.

\section{5) Tahap 5 :}

Menghitung bobot global untuk indikator kinerja. Dengan cara mengalikan bobot lokal indikator kinerja dengan bobot keterkaitan (interdependent weigths). 
TABEL XI

MENGHITUNG BOBOT GLOBAL DARI INDIKATOR KINERJA

\begin{tabular}{|c|c|c|c|c|}
\hline Perspektif BSC & $\begin{array}{c}\text { Bobot } \\
\text { Keterikatan }\end{array}$ & Indikator Kinerja & Bobot & Bobot Global \\
\hline \multirow{3}{*}{ KEUANGAN } & \multirow{3}{*}{0,386565961} & Pertumbuhan Pendapatan & 0,376720682 & 0,145627392 \\
\hline & & Peningkatan Produktifitas & 0,546520755 & 0,211266321 \\
\hline & & Optimalisasi Aset & 0,076758564 & 0,029672248 \\
\hline \multirow{3}{*}{ PELANGGAN } & \multirow{3}{*}{0,178406363} & Perolehan Pelanggan Baru & 0,234538108 & 0,041843091 \\
\hline & & Retensi Pelanggan & 0,390358366 & 0,069642416 \\
\hline & & Customer Profitability & 0,375103526 & 0,066920856 \\
\hline \multirow{3}{*}{$\begin{array}{l}\text { PROSES } \\
\text { INTERNAL } \\
\text { BISNIS (PIB) }\end{array}$} & \multirow{3}{*}{0,324771238} & Perkembangan Bisnis Principal & 0,369355401 & 0,119956011 \\
\hline & & Jasa Pengiriman Produk & 0,330669436 & 0,107391922 \\
\hline & & Promosi Produk & 0,299975162 & 0,097423305 \\
\hline \multirow{3}{*}{$\begin{array}{l}\text { PROSES } \\
\text { PEMBELAJARAN } \\
\text { DAN } \\
\text { PERKEMBANGAN } \\
(\mathrm{PP})\end{array}$} & \multirow{3}{*}{0,110256437} & Berbagi pengetahuan dan keterampilan & 0,369355401 & 0,040723811 \\
\hline & & Pelatihan Karyawan & 0,330669436 & 0,036458434 \\
\hline & & Keterbukaan berkomunikasi & 0,299975162 & 0,033074193 \\
\hline
\end{tabular}

\section{6) Tahap 6 dan 7 :}

Pada tahap ini, kinerja dari suatu perusahaan ditentukan menggunakan nilai bobot global dari indikator kinerja (Tabel 11) dan nilai linguistik yang sudah ditetapkan (Tabel 12). (evaluasi linguistik indikator kinerja sudah ditetapkan oleh tim pakar perusahaan).

TABEL XII

SKALA LINGUISTIK

\begin{tabular}{|l|l|}
\hline Nilai Linguistik & Bilangan Fuzzy \\
\hline Sangat Tinggi (ST) & 1 \\
\hline Tinggi (T) & 0,75 \\
\hline Sedang (S) & 0,5 \\
\hline Rendah (R) & 0,25 \\
\hline Sangat Rendah (SR) & 0 \\
\hline
\end{tabular}

TABEL XIII

PENGUKURAN INDIKATOR MENGGUNAKAN FANP-BSC

\begin{tabular}{|l|c|c|c|c|}
\hline \multicolumn{1}{|c|}{$\begin{array}{c}\text { Indikator } \\
\text { Kinerja }\end{array}$} & $\begin{array}{c}\text { Bobot Global } \\
\text { (BG) }\end{array}$ & $\begin{array}{c}\text { Evaluasi } \\
\text { Linguistik }\end{array}$ & $\begin{array}{c}\text { Nilai } \\
\text { Skala } \\
\text { (NS) }\end{array}$ & $\begin{array}{c}\text { Indikator } \\
\text { (BG X NS) }\end{array}$ \\
\hline $\begin{array}{l}\text { Pertumbuhan } \\
\text { Pendapatan }\end{array}$ & 0,145627392 & ST & 1,00 & 0,145627392 \\
\hline $\begin{array}{l}\text { Peningkatan } \\
\text { Produktifitas }\end{array}$ & 0,211266321 & ST & 1,00 & 0,211266321 \\
\hline $\begin{array}{l}\text { Optimalisasi } \\
\text { Aset }\end{array}$ & 0,029672248 & S & 0,50 & 0,014836124 \\
\hline $\begin{array}{l}\text { Perolehan } \\
\begin{array}{l}\text { Pelanggan } \\
\text { Baru }\end{array}\end{array}$ & 0,041843091 & ST & 1,00 & 0,041843091 \\
\hline $\begin{array}{l}\text { Retensi } \\
\text { Pelanggan }\end{array}$ & 0,069642416 & ST & 1,00 & 0,069642416 \\
\hline $\begin{array}{l}\text { Customer } \\
\text { Profitability }\end{array}$ & 0,066920856 & ST & 1,00 & 0,066920856 \\
\hline
\end{tabular}

\begin{tabular}{|l|c|c|c|c|}
\hline $\begin{array}{l}\text { Perkembangan } \\
\text { Bisnis } \\
\text { Principal }\end{array}$ & 0,119956011 & ST & 1,00 & 0,119956011 \\
\hline $\begin{array}{l}\text { Jasa } \\
\text { Pengiriman } \\
\text { Produk }\end{array}$ & 0,107391922 & $\mathrm{~T}$ & 0,75 & 0,080543942 \\
\hline $\begin{array}{l}\text { Promosi } \\
\text { Produk }\end{array}$ & 0,097423305 & $\mathrm{~S}$ & 0,50 & 0,048711652 \\
\hline $\begin{array}{l}\text { Berbagi } \\
\text { pengetahuan } \\
\text { dan } \\
\text { keterampilan }\end{array}$ & 0,040723811 & $\mathrm{ST}$ & 1,00 & 0,040723811 \\
\hline $\begin{array}{l}\text { Pelatihan } \\
\text { Karyawan }\end{array}$ & 0,036458434 & $\mathrm{~S}$ & 0,50 & 0,018229217 \\
\hline $\begin{array}{l}\text { Keterbukaan } \\
\text { berkomunikasi }\end{array}$ & 0,033074193 & $\mathrm{~T}$ & 0,75 & 0,024805645 \\
\hline \multicolumn{5}{|c|}{ Total } \\
\hline
\end{tabular}

\section{KESIMPULAN}

Fuzzy ANP merupakan suatu metode yang menggabungkan metode fuzzy dengan ANP. ANP sangat sesuai untuk kondisi dimana sangat banyak ketergantungan terjadi dalam pengambilan keputusan. Proses ANP membutuhkan data perbandingan berpasangan. Sedangkan Balanced Score Card merupakan alat pengukur kinerja yang tidak hanya mengukur kinerja dari segi keuangan saja tetapi juga dari segi non keuangan yang terdiri dari empat perspektif yang saling melengkapi dan mempunyai hubungan sebab akibat. Dengan menggunakan Balanced Scorecard, manajer tidak hanya mengukur hasil akhir, tetapi juga mengukur aktivitas-aktivitas penentu akhir.

Metode yang digunakan pada penelitian ini adalah Fuzzy Analytical Network Process (FANP) dengan Konsep Balanced Scorecard. Penelitian ini menggunakan data dari salah suatu 
perusahaan sales dan distributor di Indonesia yang memiliki visi "Sukses dan Unggul sebagai perusahaan sales dan distributor" serta memiliki tiga strategi untuk mewujudkannya. Strategi tersebut yaitu Merancang produk berdasarkan kemauan konsumen, mengembangkan teknologi yang digunakan dalam phase penjualan dan distribusi dan mengembangkan bisnis principal yang sudah ada.

Tim pakar perusahaan telah menentukan indikator kinerja berdasarkan perspektif BSC yang dapat dilihat pada Tabel 1 . Hasil dari penelitian ini adalah Perusahaan tersebut telah menjalankan perusahaannya berdasarkan indikator kinerja dari perspektif BSC yang sesuai dengan visi dan strategi menggunakan Fuzzy Analytic Network Process (FANP) sebesar $88,31 \%$.

\section{REFERENSI}

[1] V. Devani, "Pengukuran Kinerja Perpustakaan Dengan Pendekatan Balanced Scorecard," J. Ilm. Tek. Ind., vol. 15, no. 1, p. 27, 2017.

[2] M. dan Sari and T. Arwinda, "Analisis Balanced Scorecard Sebagai Alat Pengukuran Kinerja Perusahaan PT.Jamsostek Cabang Belawan," J. Ris. Akuntasi dan Bisnis, vol. 15, no. 1, pp. 28-42, 2015.

[3] I. G. Eggy, P. Wiguna, N. Gst, and P. Wirawati, "E-Jurnal Akuntansi Universitas Udayana PENERAPAN BALANCED SCORECARD PADA PENGUKURAN KINERJA TRANS SARBAGITA Fakultas Ekonomi dan Bisnis Universitas Udayana ( Unud ), Bali , Indonesia Fakultas Ekonomi dan Bisnis Universitas Udayana ( Unud ), Bali , Indones," Issn 1412-8837, vol. 21, pp. $1072-1100,2017$.

[4] E. M. H. dan A. Slamet, "Analisis Kinerja Manajemen Rumah Sakit Umum Bina Kasih Ambarawa Dengan Pendekatan Balanced Scorecard," Manag. Anal. J., vol. 1, no. 3, pp. 1-14, 2017.

[5] K. Trihastutii, "Analisis Kinerja Perusahaan dengan Metode BSC," Manag. Anal. J., vol. 1, no. 3, pp. 1-9, 2012.

[6] A. Alimudin, A. Z. Falani, S. W. Mudjanarko, and A. D. Limantara, "Analisis Pengaruh Penerapan Perspektif Balanced Scorecard Terhadap Peningkatan Kinerja UMKM," Ekonika J. Ekon. Univ. kadiri, vol. 4, no. 1, p. 1, 2019.

[7] M. P. Ismail and W. W. Winarno, "Manajemen Sumber Daya Teknologi Informasi Laboratorium Komputer Menggunakan Balanced Scorecard (BSC) dan COBIT 5," J. Infotel, vol. 9, no. 2, p. $158,2017$.

[8] A. Alimudin, "Analisis Pencapaian Strategi Menggunakan Balanced Scorecard," J. Pendidik. Ekon. Dan Bisnis, vol. 5, no. 2, pp. 178 194, 2017.

[9] Afrina and Muthmainnah, "Sistem Pendukung Keputusan Penerimaan Beasiswa Pada Rumah Zakat Dengan Metode Fuzzy Analytical Network Proces ( Fanp ) Di Baitul Mal Kabupaten Aceh Utara," vol. 2, no. 1, pp. 15-24, 2018.

[10] O. Soesanto, M. M. Shiddiq, and O. Oktarini, "Analytic Network Process (Anp) Pada Balanced Scorecard (Bsc) Dengan Pendekatan Fuzzy,” Klik - Kumpul. J. Ilmu Komput., vol. 3, no. 2, p. 205, 2018.

[11] R. Geometry and G. Analysis, "Rekayasa Perangkat Lunak Aplikasi Keputusan Multi Kriteria Dengan Algoritma Analytic Network Process Berbasis Android," J. Sist. Inf., vol. 14, no. I, pp. 33-40.

[12] R. Govindaraju and J. Pratama Sinulingga, "Pengambilan Keputusan Pemilihan Pemasok di Perusahaan Manufaktur dengan Metode Fuzzy ANP,” J. Manaj. Teknol., vol. 16, no. 1, pp. 1-16, 2017.

[13] I. Rahmayuni and I. PP Yusda, "Jurnal Momentum ISSN : 1693752X IT GOVERNANCE BALANCED SCORECARD UNTUK MENGUKUR KINERJA Jurnal Momentum ISSN : 1693-752X," Issn 1693-752X, vol. 16, no. 2, 2014.
[14]

H. Bone and M. Sholihin, "Pengaruh Perspektif Dan Jenis Ukuran Dalam,” J. Ekon. dan Keuang., vol. 16, no. 80, pp. 457-472, 2012. V. Pratiwi et al., "Analisis pengukuran kinerja perusahaan dengan menggunakan metode balanced scorecard pada perusahaan daerah air minum surakarta tahun 2015 - 2016," vol. 18, no. April, pp. 208-218, 2018. 